\title{
Stochastic Reactor-Based Fuel Bed Model for Grate Furnaces -Appendix
}

\author{
Corinna Netzer, ${ }^{*, \dagger}$ Tian Li, ${ }^{\dagger, \ddagger}$ Lars Seidel, ${ }^{\uparrow}$ Fabian Mauß, ${ }^{\S}$ and Terese Løvås ${ }^{\dagger}$ \\ $\dagger$ Department of Energy and Process Engineering, Norwegian University of Science and \\ Technology, Trondheim, Norway \\ $\ddagger R I S E$ Fire Research, Tiller, Norway \\ \LOGE Deutschland GmbH, Cottbus, Germany \\ $\S$ Chair of Thermodynamics and Thermal Process Engineering, Brandenburg University of \\ Technology, Cottbus, Germany \\ E-mail: corinna.netzer@ntnu.no
}

\section{Validation of the reduced reaction mechanism}

The following set of figures compares the predictions of the detailed scheme by Ranzi et al. ${ }^{1}$ and its reduced scheme applied in this work. Compared are ignition delay time (IDT) in Fig. A1 to Fig. A5, speciation measurements in Fig. A6 and Fig. A7 and speciation prediction of the larger gas phase species in Fig. A8 to Fig. A10. 

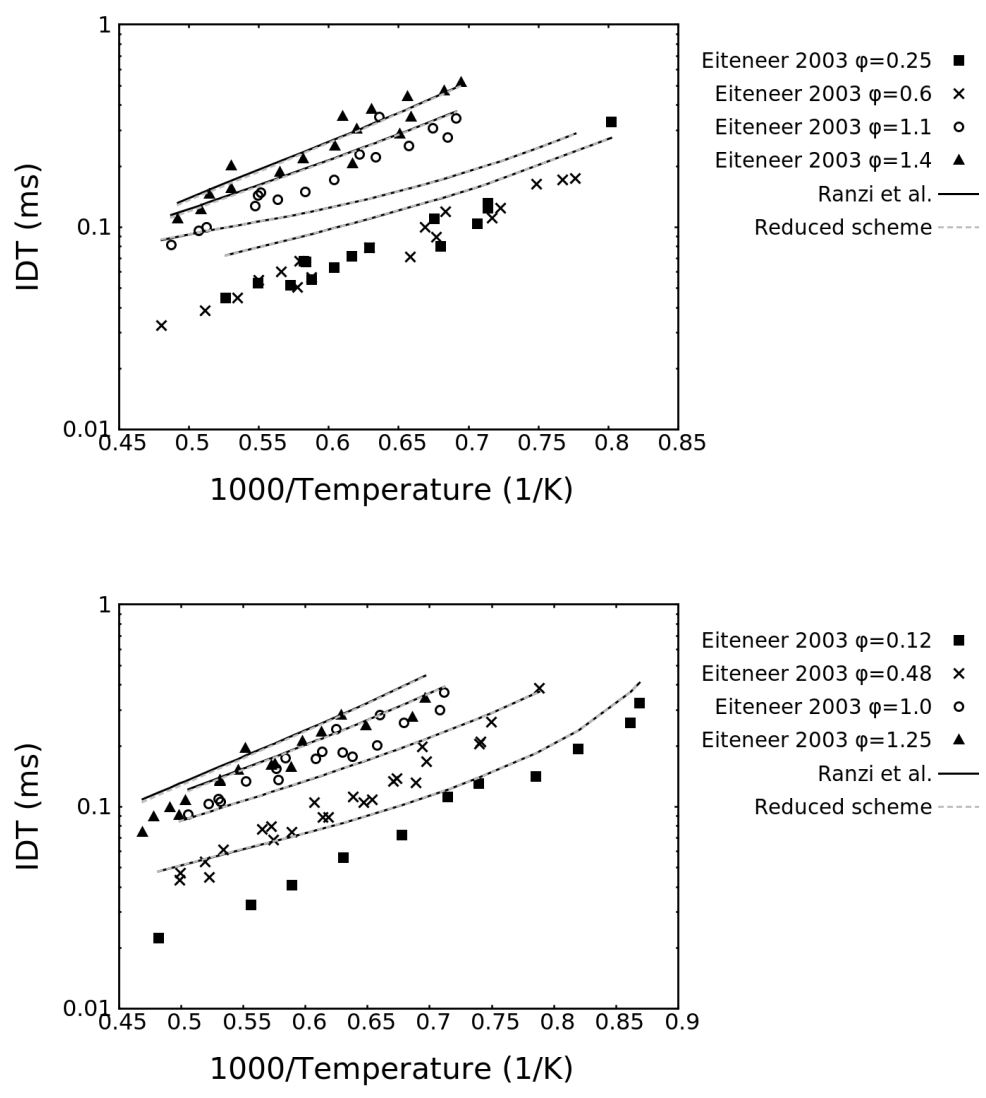

Figure A1: Shock-type data for acetylene $\left(\mathrm{C}_{2} \mathrm{H}_{2}\right)$ in oxygen/argon mixtures for various equivalence ratios and $1.1-1.25 \mathrm{~atm} .{ }^{[2]}$

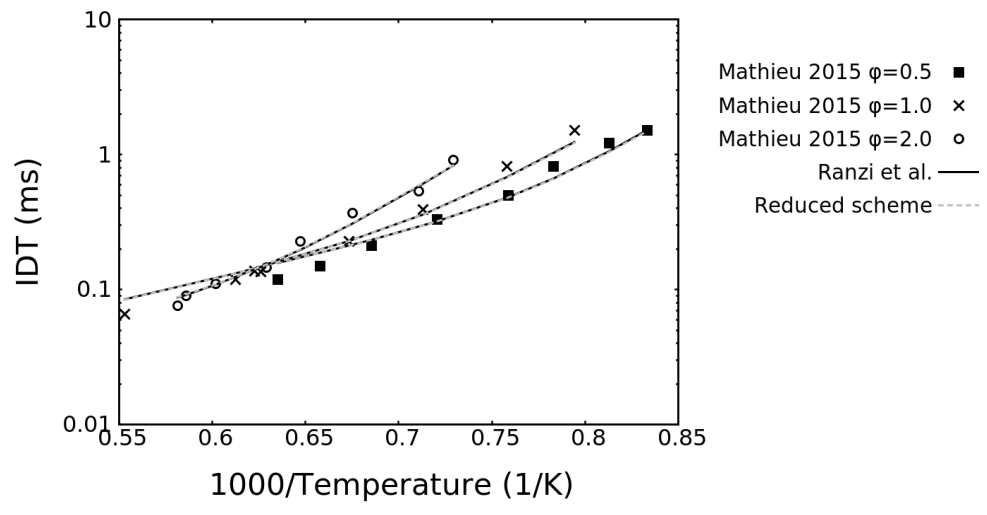

Figure A2: Shock-type data for ethylene $\left(\mathrm{C}_{2} \mathrm{H}_{4}\right)$ in oxygen/argon mixtures for various equivalence ratios and at $1.0 \mathrm{~atm} \cdot{ }^{3}$ 


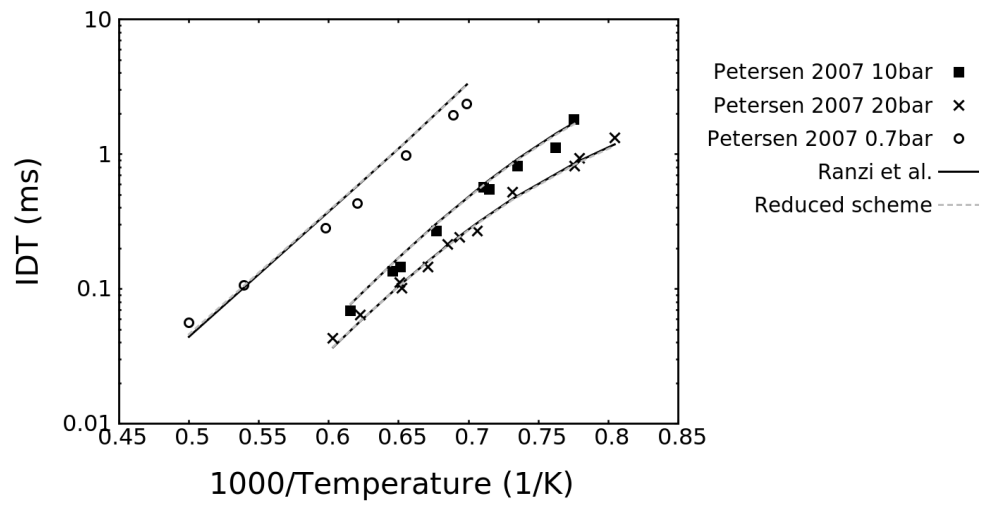

Figure A3: Shock-type data for methane $\left(\mathrm{CH}_{4}\right)$ in air for various pressures at $\varphi=0.5 . \stackrel{4}{\square}$

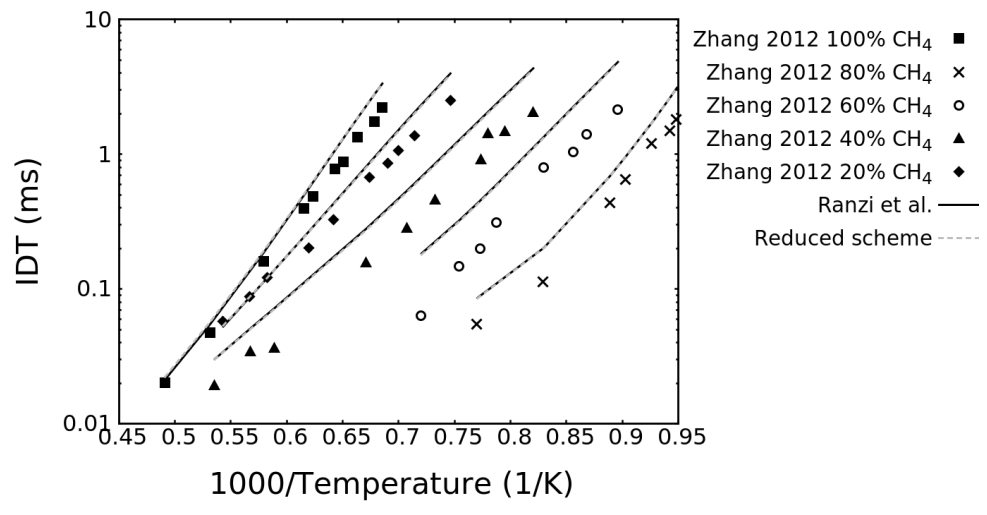

Figure A4: Shock-type data for methane/hydrogen $\left(\mathrm{CH}_{4} / \mathrm{H}_{2}\right)$ mixtures in oxygen/argon mixtures at $\varphi=0.5$ and 5 bar. ${ }^{5}$ 


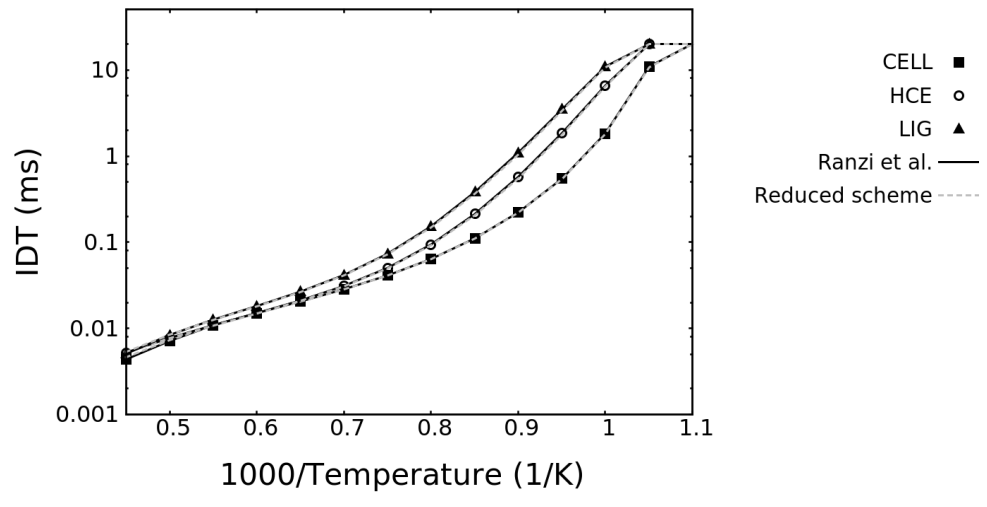

Figure A5: Ignition delay times of the predicted mixtures using the setup of Case 1 in air and $\varphi=1$. Surrogates of the solid phase by wt\%:(1) 100\% CELL; (2) 100\% HCE and (3) mixture of $33 \% \mathrm{LIG}_{C}, 34 \% \mathrm{LIG}_{H}$ and $33 \% \mathrm{LIG}_{O}$.
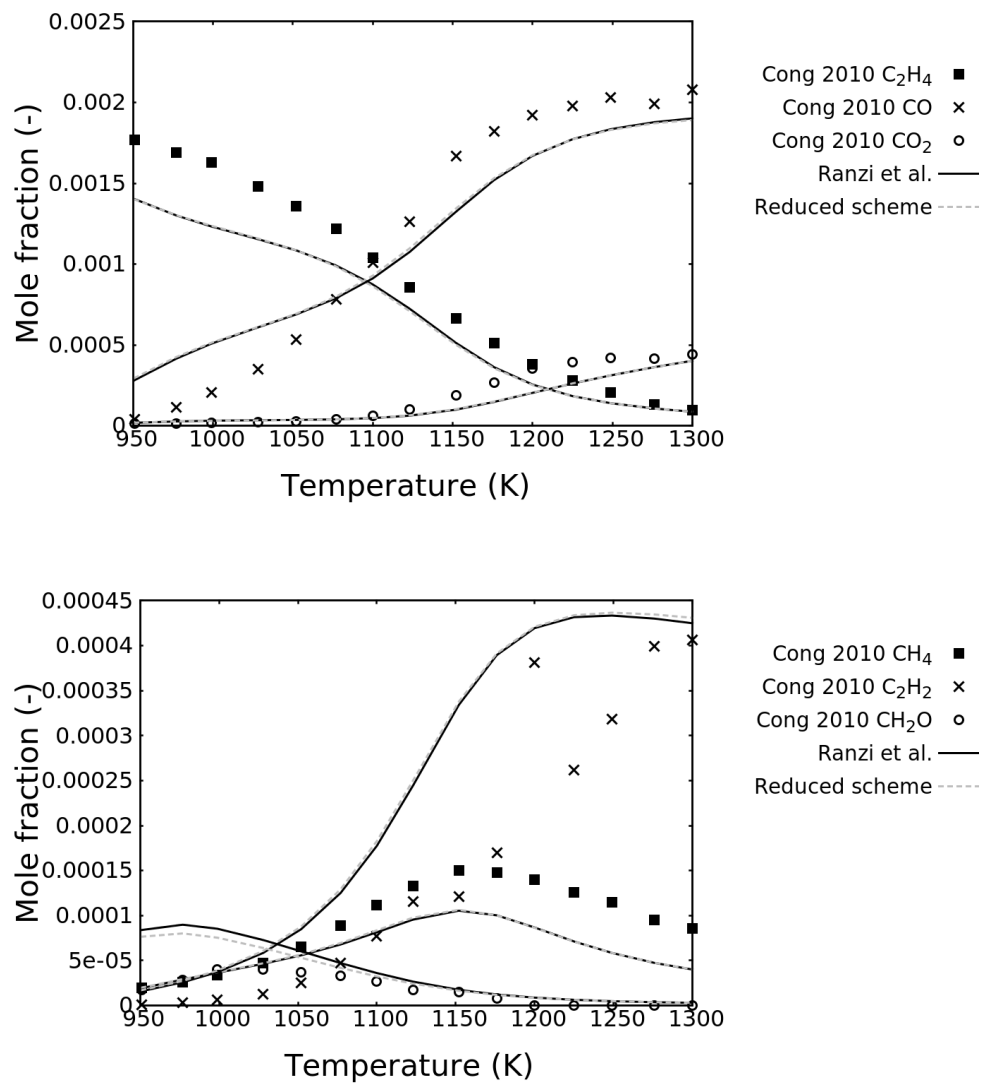

Figure A6: Jet-stirred reactor data for acetylene $\left(\mathrm{C}_{2} \mathrm{H}_{2}\right)$ in diluted air at $\varphi=2$ and $1 \mathrm{~atm} \cdot{ }^{6}$ 

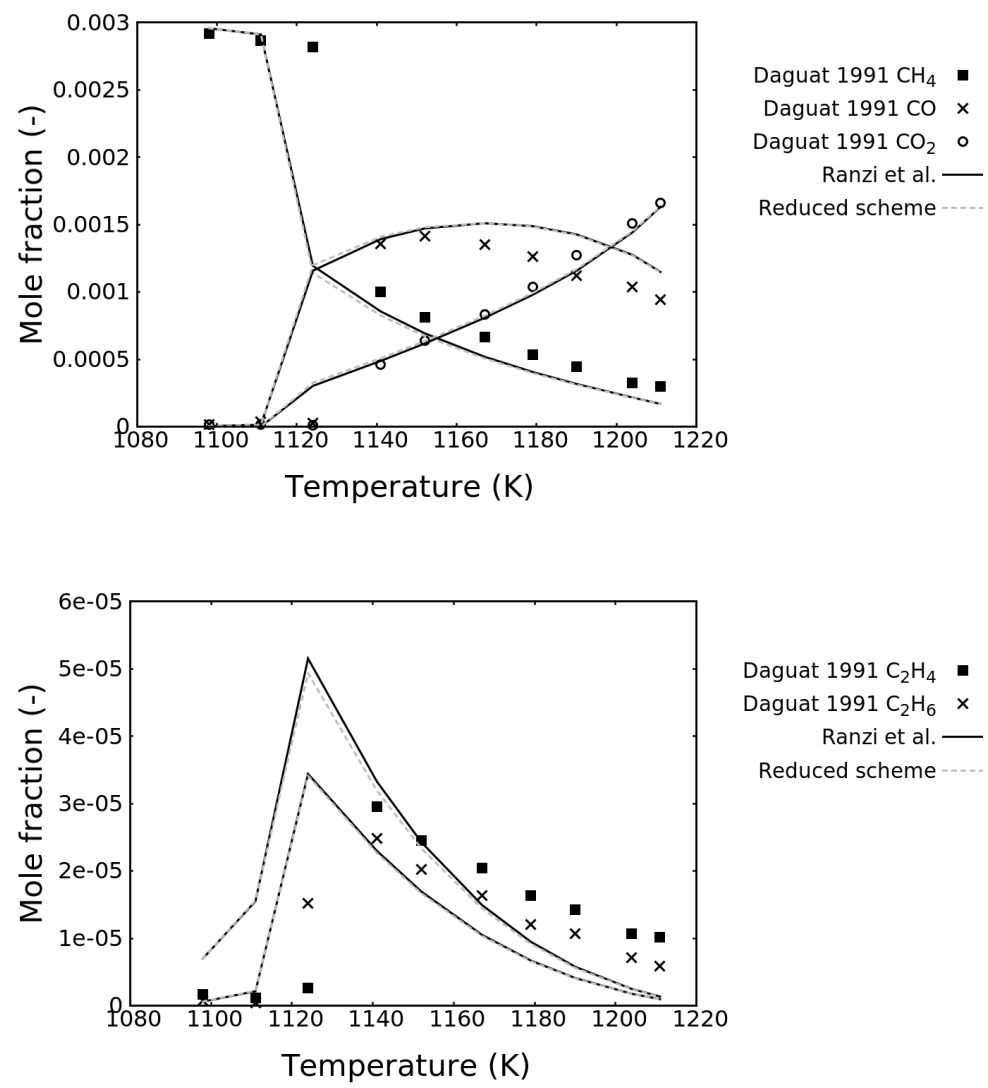

Daguat $1991 \mathrm{C}_{2} \mathrm{H}_{4}$.

Daguat $1991 \mathrm{C}_{2} \mathrm{H}_{6} \quad \times$

Ranzi et al.

Reduced scheme

Figure A7: Jet-stirred reactor data for methane $\left(\mathrm{CH}_{4}\right)$ in diluted air at $\varphi=0.1$ and $1 \mathrm{~atm} \cdot \cdot^{7}$ 

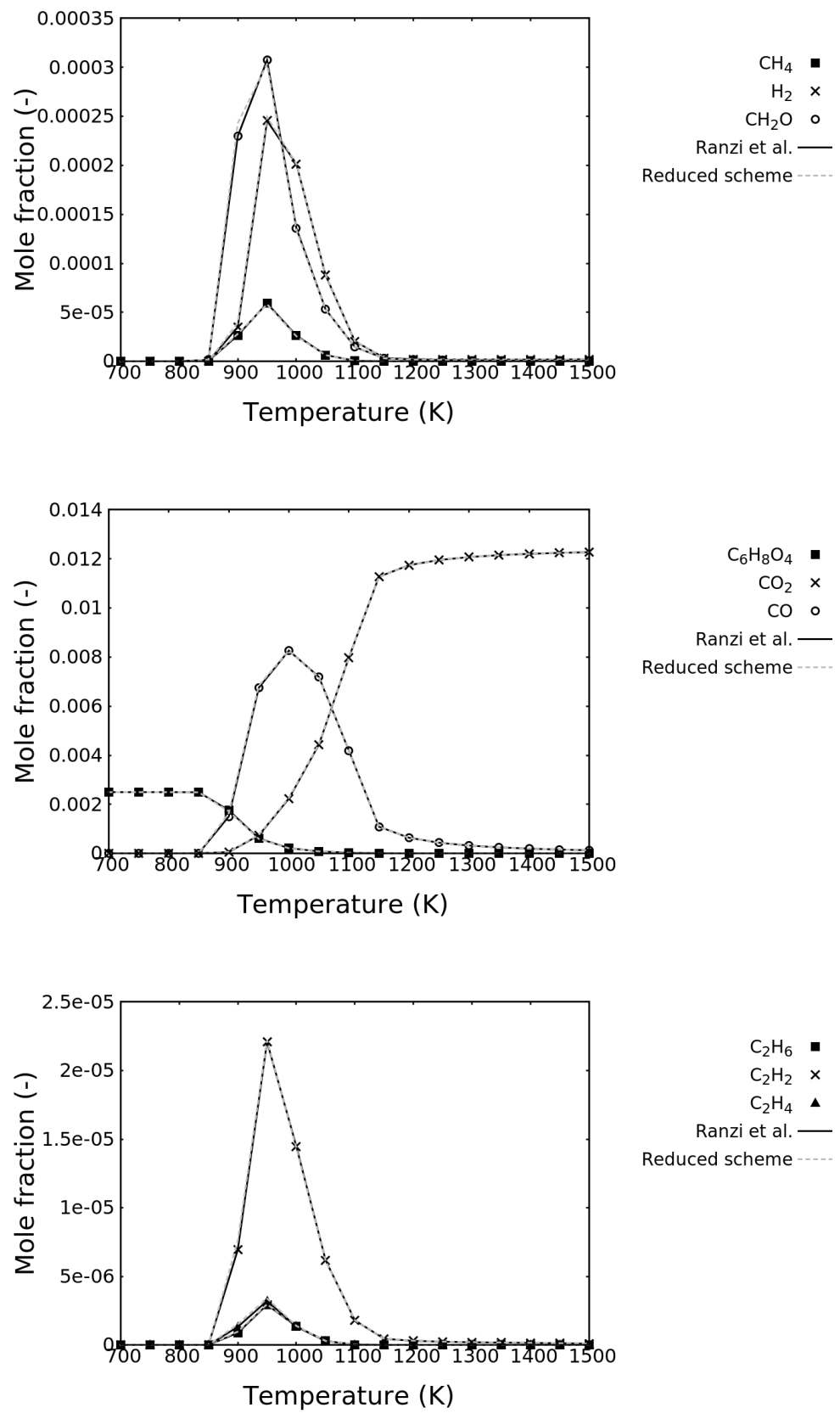

Figure A8: Speciation prediction of xylan $\left(\mathrm{C}_{5} \mathrm{H}_{8} \mathrm{O}_{4}\right)$ as product of the hemicellulose chemistry at $\varphi=0.1$ and $1 \mathrm{~atm}$. 

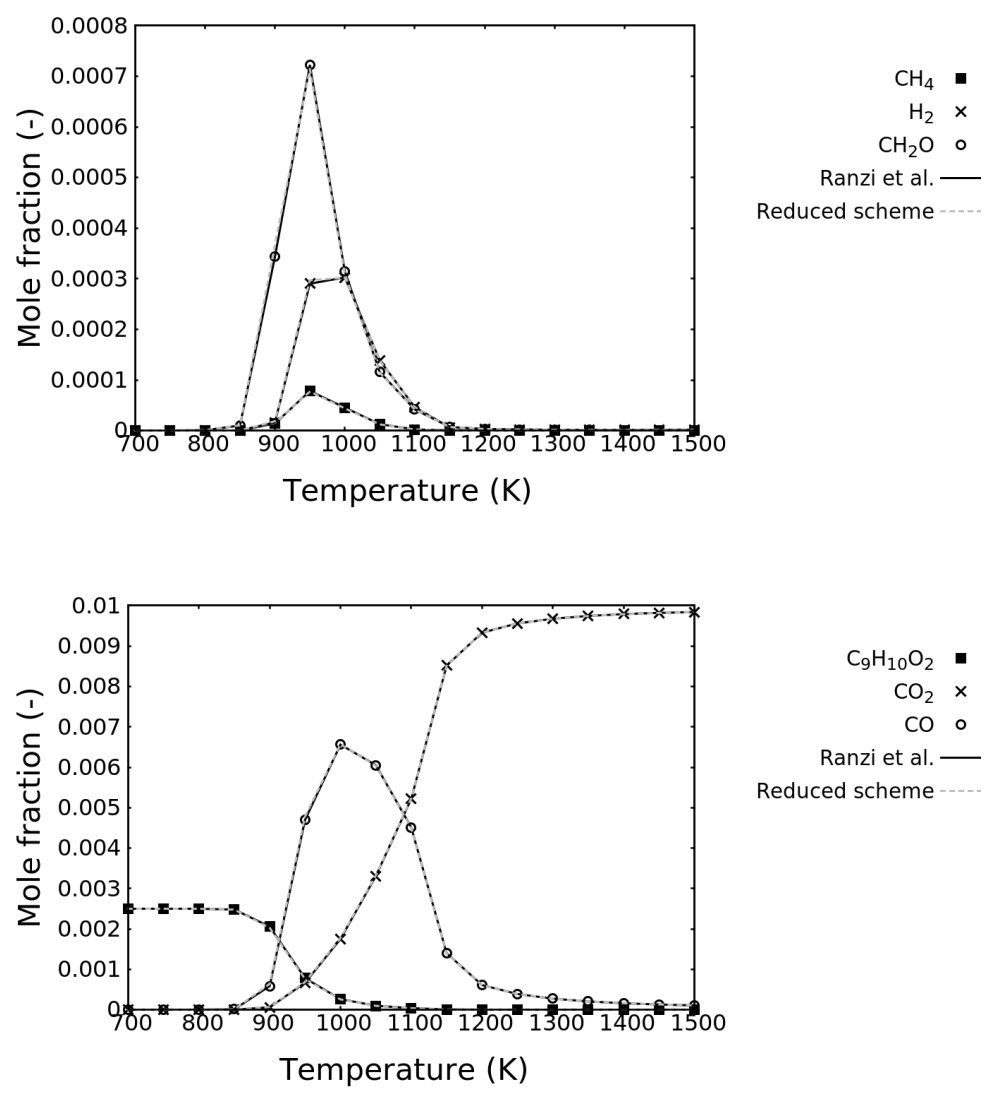

Figure A9: Speciation prediction of paracoumaryl alcohol $\left(\mathrm{C}_{9} \mathrm{H}_{10} \mathrm{O}_{2}\right)$ as product of the lignin chemistry at $\varphi=0.1$ and $1 \mathrm{~atm}$.

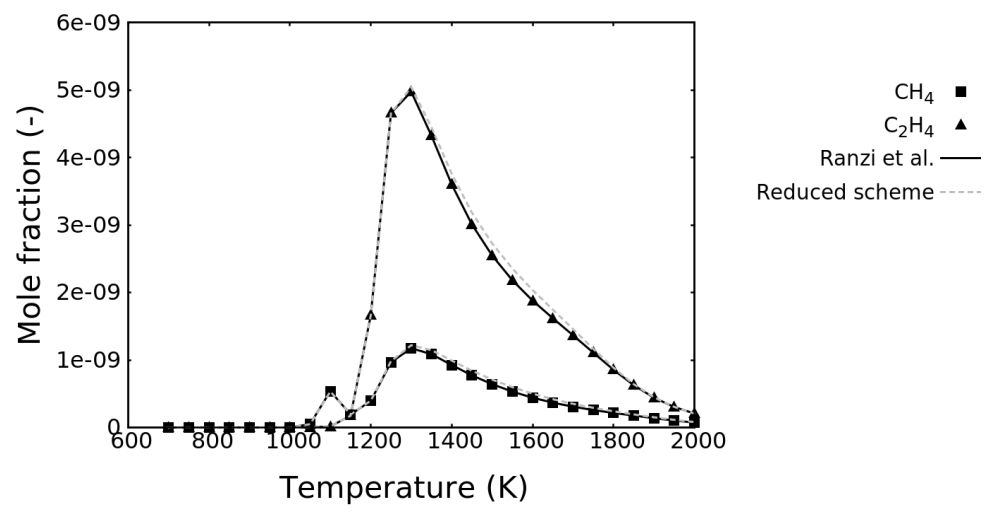

Figure A10: Speciation prediction of $\mathrm{C}_{11} \mathrm{H}_{12} \mathrm{O}_{3}$ as largest gas phase moleulce at $\varphi=0.1$ and $1 \mathrm{~atm}$. 


\section{References}

(1) Ranzi, E.; Pierucci, S.; Aliprandi, P.; Stringa, S. Comprehensive and Detailed Kinetic Model of a Traveling Grate Combustor of Biomass. Energ Fuel 2011, 25, 4195-4205.

(2) Eiteneer, B.; Frenklach, M. Experimental and modeling study of shock-tube oxidation of acetylene. Int J Chem Kinet 2003, 35, 391-414.

(3) Mathieu, O.; Goulier, J.; Gourmel, F.; Mannan, M.; Chaumeix, N.; Petersen, E. Experimental study of the effect of CF3I addition on the ignition delay time and laminar flame speed of methane, ethylene, and propane. Prog Combust Inst 2015, 35, 2731 - 2739.

(4) Petersen, E.; Hall, J.; Smith, S.; de Vries, J.; Amadio, A.; Crofton, M. Ignition of Lean Methane-Based Fuel Blends at Gas Turbine Pressures. J Eng Gas Turb Power 2007, 129, 937-944.

(5) Zhang, Y.; Huang, Z.; L.Wei,; Zhang, J.; Law, C. Experimental and modeling study on ignition delays of lean mixtures of methane, hydrogen, oxygen, and argon at elevated pressures. Combust Flame 2012, 159, 918 - 931.

(6) Cong, T.; Bedjanian, E.; Dagaut, P. Oxidation of Ethylene and Propene in the Presence of CO2 and H2O: Experimental and Detailed Kinetic Modeling Study. Combust Sci Technol 2010, 182, 333-349.

(7) Dagaut, P.; Boettner, J.; Cathonnet, M. Methane Oxidation: Experimental and Kinetic Modeling Study. Combust Sci Technol 1991, 77, 127-148. 